\title{
The Subject, It is Here! The Varying Structural Positions of Preverbal Subjects*
}

(O Sujeito, Ele Está Aqui! A Posição Variável dos Sujeitos Preverbais)

\author{
Acrisio PIRES \\ (University of Michigan, Ann Arbor)
}

\begin{abstract}
This paper analyzes preverbal overt subjects, comparing Brazilian Portuguese to (other) null-subject languages, especially within Romance. It explores syntactic and semantic properties, including resumption, ellipsis, quantifiers and scope, variable binding, ordering restrictions, pronominal distinctions, minimality violations, bare nouns and definiteness. It concludes that preverbal subjects in Brazilian Portuguese can be realized both in argumental positions (Specifier of the Inflectional or Tense Phrase) and non-argumental positions (Topic Phrase specifiers), with the possibility that both types of positions are filled by the subject in the same clause, incorporating properties that have been argued not to be found together in other languages.
\end{abstract}

KEY-WORDs: Portuguese; minimalism; subjects; comparative syntax.

* It is a great pleasure for me to have the opportunity to contribute some of my work to a volume in honor of Lucia Lobato. I am very grateful to have counted with her encouragement and friendship for many years. During her career, Lucia Lobato made crucial contributions to linguistics in Brazil, by means of her research, and by teaching and advising many students who went on to follow careers in the field. She was an extremely dedicated teacher and mentor to her students, and her own work inspired many of them in different ways. Her efforts to promote the interaction among linguists in Brazil and abroad also contributed significantly to the development of the field in Brazil. I hope Lucia's efforts and dedication to linguistics remain an inspiration to Brazilian linguists for a long time.

I would like to thank the editors of this volume, Cilene Rodrigues and Ana Paula Scher, for taking the time to edit this collection of papers in honor of Lucia Lobato, and for inviting me to contribute this paper. Thanks also to my research assistants: Gerardo Fernández-Salgueiro, for surveying part of the relevant literature on the analysis of subjects which I refer to in this paper, especially regarding analyses previously proposed for Spanish; and Amanda Gallaher, for helping with the final proofs.

D.E.L.T.A., 23:esp., 2007 (113-146) 
RESUMO: Esse artigo analiza sujeitos preverbais manifestos, comparando o português do Brasil com (outras) linguas de sujeitos nulos. O artigo investiga propriedades sintáticas e semânticas, incluindo pronomes resumptivos, elipse, quantificadores e escopo, ligação de variáveis, restrições de ordem, distinções pronominais, violações de minimalidade, nomes sem determinantes, e definitude. Concluo que esses sujeitos preverbais podem realizarse tanto em posição argumental (especificador do sintagma flexional ou temporal) quanto em posições não-argumentais (posições de tópico), com a possibilidade de os dois tipos de posiçôes serem preenchidos pelo sujeito na mesma oração, incorporando propriedades que são tidas como não ocorrendo juntas em outras linguas.

PaLAVRAs-CHAVE: Português; minimalismo; sujeitos; sintaxe comparativa.

\section{Introduction}

This paper considers a topic that has received at least two distinct approaches within the Principles \& Parameter/Minimalist syntax literature: the analytical treatment of what is often referred to as the subject of the clause. The relevance of this topic is due partly to the fact that it necessarily has consequences for the treatment of the interaction between agreement, nominative Case and arguably the existence of an EPP requirement on the inflectional/tense (Infl or T) of the clause. Even though these topics are not the main focus of this paper, a precise analytical approach to the structural realization of different clausal arguments is crucial for research in this domain to proceed, and this is what this paper focuses on.

In this respect, this paper is concerned primarily with the analysis of the structural position of DPs that occur in preverbal position, and which are interpreted either as the external argument of transitive and unergative verbs (1) or as the single overt argument of unaccusative verbs (2), as indicated in italics in the examples (examples from English):

(1) a. Sue called Bill

b. Jane dances well

(2) Anna arrived

In the empirical cases under consideration here, these argument DPs will be referred to in general as "(preverbal) subjects", and in the discussion 
that follows, I will consider different proposals that have been made to account for their structural properties, especially in Iberian Romance. ${ }^{1}$ These preverbal subjects have been standardly analyzed as being generated internally to the $\mathrm{vP} / \mathrm{VP}$, in their argument position, across languages. Different mechanisms have then been proposed to trigger their movement to Spec, IP (Spec, TP, in recent Minimalist approaches, e.g. Chomsky 1995, 2000, 2001, and in the proposal I make here), where they are overtly realized. Most recent approaches appeal to Case, Agreement and/or an EPP-requirement to trigger overt movement of the "(preverbal) subject" to Spec, TP (see, for different proposals Chomsky 1995, 2000, 2001, Epstein \& Seely 2006, Lasnik 2001).

However, especially in the literature on null-subject languages, there have been recent proposals that overt preverbal subjects are not realized in Spec, TP, but are rather left-dislocated elements that are realized within the CP domain.

The goal of this paper is to consider aspects of a few analyses or preverbal subjects that have been proposed for Spanish, Italian, and European Portuguese, and to identify to which extent an overarching analysis that takes these aspects into account can explain certain core properties associated with the relevant phenomena in Brazilian Portuguese (henceforth BP). The main argument I will make is that there is no single unified preverbal structural position where subjects are realized in BP (an argument that is also supported by some of the existing literature on the topic in BP). Given this, the notion subject (or more specifically here, preverbal subject) is in fact unclear, given that, as I will argue, it corresponds to at least two different kinds of elements in the context of this paper:

(3) Overt DPs in Spec, TP (subjects in A-position)

Argument DPs that move to Spec, TP to value their nominative Case and at the same time trigger $\mathrm{f}$-feature (person, number) agreement on the Inflectional head of the clause. ${ }^{2}$

\footnotetext{
1 One reason for their specification as preverbal subjects (and not simply subjects) is to allow clear comparison with the corresponding subset of subjects in other Romance languages such as Spanish and Italian, in which postverbal subjects are also widespread.

2 I adopt here a non-split IP approach (see e.g. Chomsky 2000, 2001; for split IP see Pollock 1989, Belletti 1990, Cinque 2002), referring to the unified Agreement/Tense projection as TP, following a common approach in Minimalism. When I review previous approaches I may make reference to IP, but for the relevant purposes IP and TP are treated identically.
} 
(4) Overt DPs in the CP domain (subjects in $\mathrm{A}^{\prime}$-position)

DPs interpreted as arguments of the verb, but which are realized within the $\mathrm{CP}$ domain of the clause. They are referred to as left-dislocated elements.

Given the two possibilities, I will usually specify whether I refer to preverbal subjects in Spec, TP or as left-dislocated elements, given that this distinction is the main focus of this paper. Notice that the DPs that move to Spec, TP can be the external argument of transitive and unergative verbs (1), or the internal argument of unaccusative (2) and passive verbs, under the standard analysis of A-movement in Principles \& Parameters. I will focus here on the realization of these DPs in Spec, TP at some point in the derivation (as opposed to a left-dislocated position in CP), putting aside detailed consideration of what triggers their movement to Spec, TP.

This paper will focus on the distinction and the interaction between the two types of elements in (3) and (4). First, I will provide detailed arguments that overt preverbal subjects in BP can in fact be realized in either position, depending on certain structural properties of the clause. This is different from what has been argued in various proposals for other Romance languages, in which arguments have been made that preverbal subjects are restricted to one or the other structural position, but are not allowed to occur in both positions. Second, I will show which properties of the preverbal subject DPs themselves may or may not play a role in restricting their occurrence to either structural position in (3)-(4), in $\mathrm{BP}^{3}$

If the results presented here are on the right track, they indicate one of two outcomes: (i) BP is substantially different from other languages that it is partially compared to here (more specifically the null subject languages Spanish, Catalan, Greek, and Italian), regarding the properties of preverbal subjects, and one or more mechanisms are necessary to explain why this difference arises; or (ii) the treatment of preverbal subjects proposed for $\mathrm{BP}$ in fact reveals a situation that may also be present (at least partially) in the other languages under consideration, in that preverbal subjects corresponding to both (3) and (4) would be possible in the individual grammar of one or more of the languages mentioned above. Outcome (ii)

\footnotetext{
3 Two questions regarding the specific treatment of the DPs in (3) and (4) will be put aside here, since they are beyond the scope of this paper: (i) whether the left-dislocated DPs in (4) should simply be treated as topics, or as a different kind of element in the CP domain; (ii) whether they are realized in the CP domain as the result of base-generation or as the result of movement.
} 
is incompatible with individual proposals that have been made for the other languages mentioned above, in that each proposal has characterized preverbal subjects as corresponding roughly either to (3) (e.g. Cardinaletti 1999, Goodall 1999, 2001, Suñer 2003) or to (4) (e.g. Alexiadou \& Anagnostopoulou 1998, Barbosa 2000, 2006, Ordóñez 1997), but not both. ${ }^{4}$ Therefore, if (ii) is the correct outcome, certain revisions may be necessary in at least some of proposals that have been made for other languages, a question that is beyond the scope of this paper. The argument made here in detail that is common to the two possible outcomes above is that $\mathrm{BP}$ in fact displays preverbal subjects that correspond to both (3) and (4), depending on the structure.

The paper is organized as follows. Section 1 reviews certain arguments that have been proposed, especially for Spanish, that preverbal subjects can only be left-dislocated elements. Section 2 considers further arguments for a left-dislocation treatment of preverbal subjects and presents my main argument that different preverbal subjects in BP can either be left-dislocated elements (arguably in Spec, TopP) or occur in Spec, TP. Sections 3 and 4 evaluate alternative arguments that have been proposed in support of a restrictive treatment of preverbal subjects, and shows that BP provides strong empirical support for a much more flexible treatment of preverbal subjects in that the two preverbal structural positions I consider are both available for different kinds of subjects. Section 5 is a brief conclusion.

\section{Spanish: preverbal subjects in the left periphery of the clause}

Ordóñez (1997) challenges the assumption that overt subjects in Romance occupy the Spec-IP (Spec, TP) position. He argues that overt preverbal subjects in Spanish are left-peripheral constituents. That is, they are overtly realized in a projection within the $\mathrm{CP}$ domain, more specifically

\footnotetext{
4 Two possible exceptions are Suñer 2003 and Costa 2000 (see also Costa 2001). Costa (2000) considers that preverbal subjects can correspond either to (3) or to (4) in European Portuguese, although in section $4 \mathrm{I}$ partially distinguish the arguments he makes for EP from what I find for BP. Suñer 2003 shows convincingly that Spanish subjects take up an A-position, but can also be leftdislocated, as many other constituents. Zubizarreta 1998 represents yet a different view based on Spanish in that she proposes an alternative treatment of Spec, TP that incorporates to it properties associated with topicalization and focus. I consider relevant aspects of these different analyses below.
} 
the Spec of a Topic Phrase (Spec, TopP). Ordóñez uses evidence from ellipsis, negative quantifier extraction, and quantifier scope to support his argument that overt subjects in Spanish are not overtly realized in the Spec, IP position.

Considering first ellipsis, Ordóñez (1997:168) argues that VP-ellipsis in Spanish affects the preverbal position in the same way, regardless of whether it is occupied by a subject or another (left-dislocated) element, as shown in italics in (5)-(7):

(5) Él le dio unos libros a Pía y Pepe también [le dio unos libros a Pía he to.her gave some books to Pía and Pepe too (to.her gave some books to Pía) 'He gave Pía some books and so did Pepe [give Pía some books]'

(6) Unos libros le dio Juan a Pía y unos cuadros también [le dio Juan a Pía (Sp) some books to.her gave Juan to Pía and some paintings too (to.her gave Juan to Pía). 'Juan gave some books toPía and some paintings too'

(7) A Pía le dio Juan unos libros y a Sara también [le dio Juan unos libros] (Sp) to Pía to.her gave Juan some books and to Sara too (to.her gave Juan some books). 'Juan gave some books to Pía, and to Sara too'

Based on examples like these, Ordóñez (1997:168-72) proposes that the preverbal subject in (5) occupies the same position as the direct object in (6) and the indirect object in (7), that is, Spec, TopP. Ordóñez argues that this treatment is motivated by the need to treat the ellipsis site in a unified way in the different cases of ellipsis. If the overt preverbal subject were in Spec, TP, the schematic structural description of the remnant of the ellipsis in both cases would be as in (8a), with the additional assumption that in cases with a left-dislocated element, and an overt postverbal subject, it is instead a pro that occupies Spec, TP (8b). This would not show the parallelism expected from the ellipsis data above, since a single-constituent remnant would be present in the case of preverbal subjects (8a), different from cases with other elements in a left-dislocated position (8b), which would have two-constituent remnants.

$\begin{array}{ll}\text { (8) a. } & \left.\mathfrak{L}_{\mathrm{TP}} \mathrm{SU} \text { también/no }\right] \\ \text { b. } \mathfrak{\leftarrow}_{\mathrm{TopP}} \mathrm{DO} / \mathrm{IO} & \left.\mathfrak{L}_{\mathrm{TP}} \text { pro también/no }\right]\end{array}$

In addition, as Ordóñez points out, if this were the appropriate analysis, the prediction is that it would be possible to substitute an overt subject for 
pro in cases of ellipsis corresponding to (8b). However, Ordóñez provides examples of VP-ellipsis showing that this substitution is in fact not possible, as indicated in italics in (9):

(9) A tí los polícias te van a detener, pero me parece que a Maria

$(\mathrm{Sp})$

to you the police $c l$ will to arrest, but to.me seems that to Maria pro/(?? el detective) no [la va(n) a detener $]$

pro/(?? the detective) not ther will to arrest)

'The police will arrest you, but it seems to me that Maria, (they)/(??the detective) will not [arrest]'

Under Ordóñez' analysis that overt preverbal subjects in Spanish can only be in a left-dislocated position, the structural description of the ellipsis remnant for the cases in (5)-(7) should be in unified as in (10), under the assumption that only pro can occupy Spec, TP, under Ordóñez' analysis:

(10) $\mathfrak{L}_{\mathrm{TopP}} \mathrm{SU} / \mathrm{DO} / \mathrm{IO} \quad \mathfrak{L}_{\mathrm{TP}}$ pro también/no ]

$\mathrm{L}_{\mathrm{TopP}} \mathrm{SU} / \mathrm{DO} / \mathrm{IO} \quad \mathrm{L}_{\mathrm{TP}}$ pro too $/$ not $]$

In the next section, I turn to the evaluation of Ordóñez's proposal regarding preverbal subjects in Spanish and evaluate his empirical arguments from the perspective of BP.

\section{Preverbal subjects in BP: left-periphery or spec, TP}

In this section, I consider different tests for the position of preverbal subjects from the perspective of $\mathrm{BP}$, considering facts from ellipsis, scope and quantification. I will conclude that both a left periphery position and Spec, TP are available positions for preverbal subjects in the grammar of BP, contrary to what has been argued from other languages by Ordóñez 1997 and by Alexiadou \& Anagnostopoulou 1998.

BP is similar to Spanish regarding VP-ellipsis, since both preverbal subjects (11) and different left-dislocated elements (e.g. a topicalized object in (12)) can be part of the ellipsis remnant (compare to the Spanish examples in (5) to (7)): 
(11) A Silvia saiu cedo e a Paula também the Silvia left early and the Paula too

'Silvia left early and so did Paula's

(12) a Maria o Paulo já convidou, e a Sara também the Maria the Paulo already invited, and the Sara too

'Paulo has already invited Maria, and Sara too'

The same behavior under ellipsis applies to cases in which the ellipsis site corresponds to a negative clause in BP, as in (13) and (14) (for ellipsis in BP, see e.g. Cyrino \& Matos 2002):

(13) A Silvia saiu cedo, mas a Paula não the Silvia left early but the Paula not 'Silvia left early, but Paula didn't'

(14) A Maria o Paulo já convidou, mas a Sara não the Maria the Paulo already invited, but the Sara not 'Paulo has already invited Maria, but not Sara'

Notice, however, that a preverbal subject pronoun can also occur in $\mathrm{BP}$, in addition to a left-dislocated subject, as I argue in detail below. The pronoun acts as a resumptive element that has to be co-referent with the left-dislocated subject, as it has been pointed out in the literature on BP (see also Galves 2001, Kato 1999, Silva 1996 and references therein, for relevant discussion):

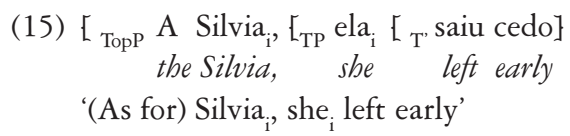

One can take the full-DP preverbal subject (Sylvia in (15)) to occupy Spec, TopP, whereas the resumptive pronoun (ela 'she') occupies Spec, TP. This proposal will be supported by different arguments in the course of this paper. I consider it first in the context of the evaluation of the ellipsis

5 Examples whose language is not specified are from BP. Data from EP and other languages are all identified in the examples. 
argument by Ordóñez. First, the resumptive pronoun shown in (15) cannot be replaced by pro in certain cases, as shown in (16) (this is in principle compatible with analyses that null referential subjects are extremely restricted in finite clauses in BP, such as Duarte 1995, Rodrigues 2004 and references therein; Modesto 2000 proposes an A'-bar binding analysis that makes different predictions):

(16) ?? $\mathrm{L}_{\mathrm{TopP}}$ A Silvia ${ }_{\mathrm{i}}, \mathrm{L}_{\mathrm{TP}} \operatorname{pro}_{i}$ saiu cedo]]
the Silvia, pro left early

However, given the argument that an overt resumptive pronoun can occupy Spec, TP in BP, this leads to the possibility of an extended ellipsis remnant that is not identified by Ordóñez for Spanish, showing both a left periphery subject in Spec, TopP and an overt resumptive pronoun in Spec, $\mathrm{TP}$, as indicated in italics in (17a-b), in the affirmative and negative ellipsis cases:

(17) a. A Silvia, ela saiu cedo e $\overleftarrow{L}_{\mathrm{TopP}}$ a Paula, $\left[_{\mathrm{TP}}\right.$ ela também $]$ ] the Silvia, she left early and the Paula, she too 'Silvia, she left early and Paula, she did too'

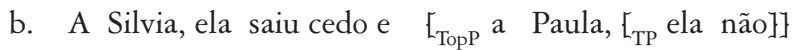
the Silvia, she left early and the Paula, she not 'Silvia, she left early and Paula, she did not'

The evidence from ellipsis in BP above also give clear support to the view advocated by Ordóñez that preverbal subjects can occur in a leftdislocated position. However, BP is distinct so far in that an overt resumptive pronoun can also occupy Spec, TP, as in (15)-(17).

I showed in (17) that an overt resumptive pronoun could occur in Spec, TP, in addition to the subject in Spec, TopP. However, (17) does not address the additional question of whether a full subject DP can occur as part of the ellipsis remnant in addition to a left-dislocated element, also different from what Ordóñez reports for Spanish (cf. (9)). A restriction similar to Spanish arises in BP in cases corresponding to (9), in that a full DP that is disjoint in reference from the subject of the antecedent clause is not possible. However, I argue that an overt subject is actually possible in Spec, TP in BP, even in the structure of the ellipsis remnant (although this overt subject faces restrictions regarding co-reference in VP-ellipsis, as I 
show below for (18)). In the first clause (18), a full DP (os policiais federais 'the federal police') can occur as the overt subject in Spec, TP, after an object in Spec, TopP. In addition, either a resumptive pronoun or an epithet ('the bastards') can occur in addition to a left-dislocated DP as part of the ellipsis remnant, in (18). The only apparent restriction in BP is that both the pronoun and the epithet in the ellipsis remnant in (18) are required to occur in co-reference with the subject of the antecedent clause (this is potentially similar to what happens in (9) in Spanish, although Ordóñez did not clarify whether an overt element was possible in Spec, TP in the ellipsis remnant in (9): ${ }^{6}$

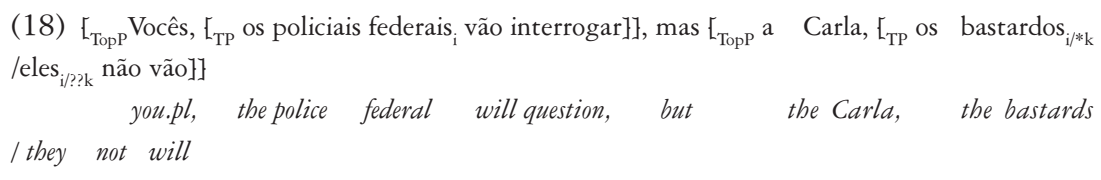

'You guys, the federal police ${ }_{\mathrm{i}}$ will interview (you); as for Carla, the bastards $\mathrm{i}_{\mathrm{i} / \mathrm{k}_{\mathrm{k}}} /$ they $_{\mathrm{i} / \text { ??k }}$ won't'

In sum, the facts above show that both Spec, TopP and Spec, TP are available as positions for overt subjects in BP, and both subject positions simultaneously, or only one position can be occupied in a single clause.

Notice, in addition, that there is no restriction that subject pronouns occur only in Spec, TP, given pairs such as (19) (in section 3, I will make a restriction regarding weak pronouns only). Notice, however, that the element in Spec, TP has to be resumptive (as a pronoun or an epithet), and co-referential with the left-dislocated DP in this case, and the left-dislocated DP can only be interpreted as the subject of the main verb, as shown by the contrast between (19b) and (20a), under a non-parenthetical interpretation of 'Paul and Sylvia' in (20a). ${ }^{7}$ The contrast arises presumably only because Binding Principle $\mathrm{C}$ blocks the co-referential interpretation in (20a), which becomes ungrammatical under any reading. Notice that

\footnotetext{
6 However, even a disjoint interpretation can be construed for the pronoun, say, under a contrastive focus intonation and if the ellipsis clause is also affirmative:

(i) Vocês, a diretora ${ }_{i}$ vai entrevistar, e a Carla, ELE $_{k}$ vai (indicando um contador) you-Pl, the director.fem $m_{i}$ will interview, and the Carla, $H E_{k}$ will (pointing an accountant) 'You guys, the director will interview (you), and Carla, HE will (Pointing to an accountant)'

7 Conversely, (19b) should not yield a violation of Binding Principle B, although important questions arise here that are beyond the scope of this paper, including also the nature of resumption in these and other cases.
} 
neither restriction rules out (20b) under the disjoint interpretation 'Paulo and Sylvia', given that 'he and she' can be interpreted as a topicalized object:

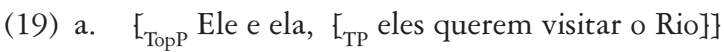
be and she they want visit the Rio

'He and she, they want to visit Rio'

b. $\mathrm{E}_{\mathrm{TopP}}[\mathrm{O} \text { Paulo e a Silvia }]_{\mathrm{i}}, \mathrm{E}_{\mathrm{TP}}$ [ele e ela/os benditos $]_{\mathrm{i}}$ querem visitar o Rio $\left.]\right]$ the Paulo e the Silvia be and shelthe blessed want visit the Rio

'Paulo and Silvia, he and she /they [the blessed ones] want to visit Rio'

(20) a. $*\left[_{\text {TopP }} \text { [Ele e ela }\right]_{i},\left[_{\mathrm{TP}} \text { [o Paulo e a Silvia }\right]_{\mathrm{i} / \mathrm{k}}$ querem visitar o Rio $]$ ] he and she the Paulo and the Silvia want visit the Rio

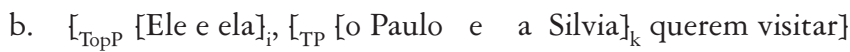
be and she the Paulo and the Silvia want visit

'He and she $]_{\mathrm{i}}$, [Paulo and Silvia $]_{\mathrm{k}}$ want to visit (them $\mathrm{i}_{\mathrm{i}}$ '

Let us turn now to a different empirical test. Ordóñez notes that in a configuration in which an embedded wh-object is moved to the matrix clause, one should consider whether the embedded subject stays in a postverbal or a preverbal position will trigger different interpretations with respect to scope, in Spanish. In (21)-(22), there are partially different scope possibilities:

(21) ¿Aquién dices que amaba cada senador?

to whom say.2SG that loved each senator

[whom $>$ each, each $>$ whom]

'Who did you say each senator loved?'

(22) ¿Aquién dices que cada senador amaba?

to whom say.2SG that each senator loved

[whom $>$ each, *each $>$ whom]

Who did you say each senator loved?

Ordóñez argues that an asymmetry follows if the preverbal subject 'each senator' in (22) has moved to an A'-position, which would freeze its scope only to narrow scope, with respect to 'whom'. In (21), however, the postverbal subject is taken to be in an A-position, from which it can further raise above a quién at LF to also allow the wide scope reading (each $>$ whom). This is based on the argument that movement/occurrence of a quantifier in an A'-position (22) freezes its scope (Barss 1986). 
Consider now the corresponding facts in BP. ${ }^{8}$ Different from Spanish, in $\mathrm{BP}$ the preverbal subject does display scope ambiguity, as shown in (23). In fact, the wide scope interpretation for cada senador 'each senator' seems to be preferred, say, such as when one answers the question with: Cada senator convidou o próprio pai 'Each senator invited his own father'. The same kind of scope ambiguity arises in (24), in which one could answer, say, o Papai Noel 'Santa Claus' or a própria mãe 'their own mother', depending on whether the scope of the quantifier 'all' is narrow or wide with respect to 'who', respectively. This indicates that the preverbal subject in (23)-(24) cannot be analyzed in the same way as the Spanish counterpart in (22), as occurring in an $\mathrm{A}^{\prime}$-position as the result of movement. Given the scope ambiguity, I argue that in cases such as (23)- (24) the preverbal subject actually moves to Spec, TP, an A-position.

(23) Quem você disse que cada senador convidou?

who you said that each senator invited

[who $>$ each, each $>$ who]

'Who did you say each senator invited?'

(24) Quem você acha que toda criança adora?

who you think that all child adores

[who $>$ all, all $>$ who]

'Who do you think each child loves?'

However, similar to Ordóñez (1997), Anagnostopoulou \& Alexiadou (1998) (henceforth A\&A) also propose that in various languages, including Spanish and Greek, there is no preverbal A-position, based on distributional, interpretational, and binding evidence. Their interpretational evidence is similar to the one used by Ordóñez. A\&A claim that preverbal subjectQPs have unambiguous scope, while postverbal ones have ambiguous scope, as shown in the Greek examples in (25). Under their analysis, this is supported by the idea that a quantifier preserves its scope properties (and remains ambiguous regarding scope) when it moves to an A-position (e.g. van Riemsdijk \& Williams 1986, May 1985), but not when it is realized in an $A^{\prime}$-position. If the preverbal subject in Greek is an $A^{\prime}$-position, this explains why 'some' can only have wide scope in (25a):

8 Only with a preverbal subject in BP, since postverbal subjects are extremely restricted (see Kato 2000 and Pilati 2006 for detailed discussion about postverbal subjects in BP). 
(25) a. Kapios fititis stihiothetise kathe arthro some student filed every article

'Some student filed every article' [some $>$ every, *every $>$ some]

b. Stihiothetise kapios fititis kathe arthro filed some student every article [some $>$ every, every $>$ some] 'Some student filed every article'

Again, corresponding evidence with a preverbal subject in BP indicates a different behavior from what A\&A point out for Greek, in that scope ambiguity obtains in BP. In (26), it is possible that each one of the students read all the articles ('some students' takes wide scope) or that all the articles were read by the group of students, even though some students may have missed some articles ('some students' takes narrow scope). It is still the case that the wide scope reading for alguns estudantes 'some students' is preferred, but it is not required, contrary to what A\&A seem to argue for Greek. Notice that an example with a different choice of quantifiers yields the ambiguity much more easily. In (27), the interpretation in which a single book by Jules Verne was read by all the students (wide scope for um ' $a$ ') is readily available. The presence of scope ambiguity with preverbal subjects in BP is again compatible with the view that these preverbal subjects can occupy an A-position (Spec, TP) in the grammar of BP.

(26) Alguns estudantes leram todos os artigos

some students read all the articles

'Some students read all the articles'

[some $>$ all, all $>$ some]

(27) Todos os estudantes leram um livro do Júlio Verne all the students read a book of. the Jules Verne

'All the students read a book by Jules Verne'

[a $>$ all, all $>$ a ]

Finally, Ordóñez points out that negative quantifiers can also occur in the preverbal position in Spanish, regardless of whether they are the subject of the sentence (28a) or some other grammatical function (29a)-(30a). However, as Ordóñez notes, when the left-dislocated quantifier is a direct or indirect object (29a)-(30a), the subject of the sentence has to be postverbal. As Ordóñez argues, this would in principle be unexplained if overt subjects 
in Spanish occupied an internal IP position. Assuming that the preverbal negative quantifier in (29)-(30) occupies a left-periphery position, nothing would block a preverbal subject if this subject could occur in a lower preverbal position, Spec, IP. Given that a preverbal subject can only occur in a left periphery position in Spanish, presumably competing with the topicalized quantifier, a preverbal subject is blocked in cases such as (29)-(30).

(28) a. Nadie le debe la renta a María

no.one to.her owes the rent to María

b. Ninguém deve o aluguel para a Maria

nobody owes the rent to the Maria

'Nobody owes rent to Maria'

(29) a. Nada (* Juan) les debe (Juan) a sus amigos

nothing (the Juan) to.them owes (Juan) to his friends

'Juan does not owe anything to his friends'

b. *Nada (*o João) deve (*?o João) aos seus amigos

nothing (the João) owes (the João) to.the his friends

(30) a. A nadie (*Juan) le debe (Juan) la renta

to no.one (*Juan) to.bim owes (Juan) the rent

'Juan owes rent to nobody'

b. *A ninguém (*o João) deve (*o João) o aluguel

to nobody (the João) owes (the João) the rent

BP also displays a contrast between the two cases at stake here. However, the contrast is of a different sort. A negative quantifier can be a preverbal subject in BP, as shown in (28b). Nevertheless, I argue that negative quantifiers cannot be topicalized in BP. ${ }^{9}$ If this is the case, then the negative quantifier subject in (28b) has to be realized in Spec, TP. This is further supported by the fact that the counterparts of (29)-(30) are both ungrammatical in $\mathrm{BP}$, independently of whether the subject is preverbal or postverbal (postverbal subjects being in general very restrictive in $\mathrm{BP}$, see

9 In fact, it seems that bare quantifiers in general are banned from topic position in BP (see below for arguments from Goodall 2001 from Spanish):

(i) * Alguém, eu chamei para me ajudar

someone, I called to me belp 
fn. 8), because they would require the topicalization of the negative quantifier, which is not possible in BP.

Interestingly, Goodall (2001) also argues that preverbal subjects are not in a topic position even in Spanish (see also Goodall 1999). One of his pieces of evidence involves quantifiers as well. He argues that while bare quantifiers cannot be topics in Spanish (31a), they can be preverbal if they are subjects (32a), in his terms (under the current analysis, if they are in Spec, TP). The same contrast arises in BP; a bare quantifier cannot be topicalized, but it can be realized as a subject in an A-position, in Spec, TP (32b):

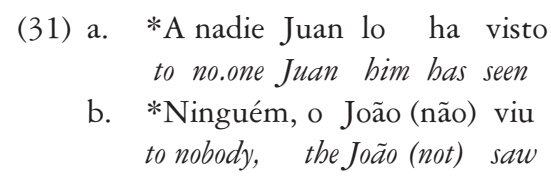

(32) a. Nadie ha visto a Juan no.one has seen to Juan

b. Ninguém viu o João nobody saw the Joano 'No one saw Juan/João'

In sum, the different empirical phenomena above support the view that preverbal subjects can occur both in a left periphery position (arguably Spec, TopP) or in an A-position (Spec, TP) in BP. Specific restrictions arise, arguably resulting from different properties, such as the fact that negative quantifiers in general cannot be left-dislocated/topicalized, but they are not dependent upon any impossibility of projection of either Spec, TP or Spec, TopP, in different structures.

\subsection{More evidence that BP subjects can be in spec, TP}

As I pointed out above, Anagnostopoulou \& Alexiadou (1998) (A\&A), similarly to Ordóñez (1997), propose that there is no preverbal A-position in Romance, based on distributional, interpretational, and binding evidence. I discussed how their interpretational evidence involving scope yields different results in BP. 
As distributional evidence, A\&A note that in Spanish the subject competes with adverbs for the preverbal position, as shown by the contrast in (33). A\&A adopt Zubizarreta's (1992, see also 1998) analysis, under which there is a single preverbal $\mathrm{A}^{\prime}$-position:

(33) a. Temprano salía Julia de casa

early left Julia of house

'Julia used to leave her house early'

b. *Temprano Julia salía de casa

early Julia left of house

When we consider BP, we can see that in cases in which an adverbial is topicalized the only option (34) is one that matches exactly the word order of the ungrammatical case (33b) from Spanish. This indicates that the preverbal subject and the topicalized adverbial do not compete for the same position in BP. This again supports the argument that the preverbal subjects can occupy Spec, TP in BP. Notice, however, that it is also possible for the preverbal subject to occur as a left-dislocated element, together with a resumptive pronoun in Spec, TP and with the topicalized adverbial, in different orders, as shown in (35). In both cases in (35) Júlia needs to be interpreted as a topic, most likely mentioned in the preceding discourse. This is different from what A\&A and Zubizarreta seem to propose for Spanish, because more than one left-dislocated element can occur in the same clause in BP. Crucially, this again indicates that both a left-dislocated position and Spec, TP can be occupied by DPs interpreted as the subject. ${ }^{10}$

(34) Hoje cedo a Júlia saiu de carro today early the Júlia left of car

'This morning Júlia left by car'

10 As also noticed by an anonymous reviewer, BP allows other topicalized elements (e.g. an adjunct PP) followed by a doubled subject (if the context is appropriate to license two topicalized elements):

(i) Com o Saul, a Irene, ela não casa de jeito nenhum

with the Saul, the Irene, she not marry of way none

'As for Saul, Irene will definitely not marry'

These different possibilities in terms of word order relate to evidence that has been taken to support the view that BP is a discourse-oriented language (Negrão 1999, Negrão \& Viotti 2000, Pontes 1987 and references therein). 
(35) a. A Júlia, hoje cedo ela saiu de carro the Júlia, today early she left of car 'Júlia, this morning, she left by car'

b. Hoje cedo a Júlia, ela saiu de carro today early the Júlia, she left of car

'This morning, Júlia, she left by car'

Turning to binding evidence considered by A\&A, they note that the so-called Montalbetti (1984) effects only appear when a pronoun is preverbal, as shown in the Catalan examples in (36). That is, assuming that only pronouns in A-positions can be construed as bound variables (cf. Barbosa 1996), the facts in (36) follow if the preverbal ells 'they' is in an A'-position in (36a), but not in (36b).

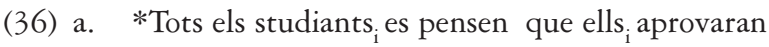
(Cat) all the students think that they pass

b. Tots els studiants ${ }_{i}$ es pensen que aprovaran ells all the students think thatpass they

As we consider the BP data, we can see once more that preverbal subjects display a distinct behavior. In (37), the preverbal pronoun can be construed as a bound variable, differently from the Catalan case:

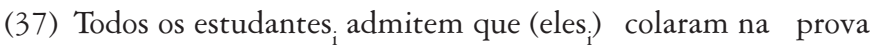
all the students admit that they cheated in.the exam 'All the students admit that they $_{\mathrm{i}}$ cheated in the exam'

Notice, however, that in (37) the preverbal pronoun can be omitted, in favor of a null subject (see Rodrigues 2004 for relevant analysis of related cases), which may affect the judgments of the overt bound variable. ${ }^{11}$ Nevertheless, when the preverbal pronoun is further embedded, it is more difficult (if at all) to drop it, and it can still be interpreted as a bound variable: ${ }^{12}$

11 In addition, the overt pronoun cannot be construed with a bound variable with a negative quantifier:

(ii) Ninguém admite que pro $_{i}$ ? ? ele $e_{i}$ colou na prova

no one admits that be cheated on.the exam

'No one admits that he cheated on the exam'

12 An anonymous reviewer points out that this was also observed by Ferreira (2000), in the context of an analysis of null subjects. 


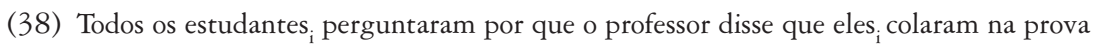
all the students asked why the teacher said that they cheated in.the exam 'All the students ${ }_{\mathrm{i}}$ asked why the teacher said they ${ }_{\mathrm{i}}$ cheated in the exam'

As I already mentioned, Goodall (2001) argues that even in Spanish preverbal subjects occupy the Spec-IP position (or Spec, TP, satisfying the EPP in Tense, in his analysis), contrary to what is indicated by the results from Ordóñez 1997, summarized in section $1 .{ }^{13}$ First, Goodall shows that a sentence with a preverbal subject (39a), as opposed to one with a leftdislocated element (40a), is a felicitous answer to a "what happened?" question. A similar situation arises in BP, in that a sentence with a preverbal, non-left-dislocated subject is felicitous in this context (39b), whereas a sentence with a left-dislocated element is not, as in (40b), in which the object $o$ anel de noivado 'the engagement ring' cannot be left-dislocated, in an answer to the question $O$ que aconteceu? 'what happened?'. Crucially, even if the preverbal subject itself is left-dislocated (a possibility that I showed does apply in other contexts in BP) the corresponding sentence (39c) is also not felicitous as an answer to 'What happened?', different from (39b), in which the preverbal subject is presumably in Spec, TP:

(39) a. Juan me regaló el anillo en el parque

Juan me gave the ring in the park

'Juan gave me the ring at the park'

b. O Paulo me deu o anel de noivado no parque

the Paulo me gave the ring of engagement in.the park

'Paulo gave me the engagement ring in the park.'

c. ?? O Paulo, ele me deu o anel de noivado no parque the Paulo, he me gave the ring of engagement in.the park

(40) a. \# En el parque me regaló (Juan) el anillo in the park me gave Juan the ring

b. \# $\mathrm{O}$ anel de noivado, o Paulo me deu no parque the ring of engagement, the Paulo me gave in.the park

\footnotetext{
13 In a different analysis, Contreras (1991) argues that preverbal subjects in Spanish result from adjunction of the DP subject to the left of the VO complex. However, he argues that Spanish lacks a Spec (IP) position. Given the substantial difference of approach, I put aside here the evaluation of the consequences of that analysis for BP.
} 
These facts provide additional evidence that BP preverbal subjects can (and in fact have to, in certain cases) be realized in an A-position, arguably Spec, TP. In the next section, I analyze various other phenomena to further support the argument that both a left-dislocated position (arguably Spec, TopP) and Spec, TP are possible positions where preverbal subjects can be realized in BP, different from more restrictive analyses that have been proposed based on other languages.

\section{More evidence for the varying position of preverbal subjects}

The sort of evidence presented for BP in section 2 is at least partially compatible with a proposal made by Cardinaletti (1999). Contrary to Ordóñez (1997), A\&A, and others, Cardinaletti argues that preverbal subjects in Romance do not necessarily occupy an A'-position. She provides evidence involving overt weak subject pronouns in Italian and also argues that a subject can be unambiguously shown to occupy a position 'internal' to the sentence (i.e. within TP).

Consider first (41), which shows that Italian pronouns of the eglilesso series cannot be left-dislocated, even when they appear pre-verbally. As Cardinaletti (1999:43) argues, this provides evidence that Null Subject languages (NSLs) can "possess preverbal subjects which behave just like subjects in non-NSLs".

(41) a. *Egli a Gianni [pro non gli ha parlato]

be to Gianni not to-him has spoken

b. *Essa questo problema [pro non lo spiega] it this problem not it explains

BP shows evidence of a different but related kind involving the use of overt weak pronouns. ${ }^{14}$ Colloquial dialects display at least two pronouns, você/vocês, 'you.sg/you.pl' that allow a reduced variant cê/cês. Interestingly, there in one clear restriction on the position in which this reduced form

\footnotetext{
14 As shown in recent proposals I cited before, BP displays a restricted distribution for null subject pro of the kind found in other NSLs. Therefore, it does not allow null subject pro as freely as, say, Italian does.
} 
can occur, in that it cannot occur before a left-dislocated element (42b). In fact, despite the analysis I proposed above that even a subject pronoun can occur as a left-dislocated element (in Spec, TopP), only the full form of you (você/vocês) can occur in this position, whereas the reduced form is restricted to Spec, TP, as shown by the contrast in (43). The contrast between the full and the reduced form of você(s) 'you' can be naturally cast in terms of a strong/weak pronoun distinction, along the lines of work by Cardinaletti \& Starke (1999) that has also been developed for BP by Britto (2001) and Kato (1999), among others.

(42) a. Você, o seu pai cê pode convidar you, the your father you can invite

'As for you, your father, you can invite'

b. *Cê, o seu pai cê pode convidar you, the your father you can invite

(43) a. Você, (vo)cê pode convidar o seu pai

you, you can invite the your father

'You, you can invite your father'

b. *Cê, cê pode convidar o seu pai you, you can invite the your father

Notice that the word order restrictions applying to preverbal pronouns extend to other cases. If the pronoun is realized as a resumptive pronoun in Spec, TP, this prevents it from preceding any left-dislocated element, as shown by the contrast below: ${ }^{15}$
(44) a. O Pedro, esse livro $\left[_{\mathrm{TP}}\right.$ ele leu] the Pedro, this book he read
'Pedro, this book he read'
b. *O Pedro, $\Sigma_{\mathrm{TP}}$ ele esse livro leu] the Pedro, be this book read

Finally, possibly given the absence or restriction on the occurrence of null subject pro in BP, once a preverbal subject is unambiguously realized

15 I address below the possibility of multiple left-dislocated elements in the clause. 
in a left-dislocated position, the Spec, TP position has to be occupied by an overt resumptive pronoun, as shown by the ungrammaticality of (45) with a null subject in Spec, TP, in contrast with (44a):

(45) *O Pedro, esse livro pro leu the Pedro, this book pro read

Cardinaletti (1999) also shows that in Aux-to-Comp movement and complementizer-deletion contexts, preverbal subjects are allowed in Italian (46a), yet left-dislocated elements are not (46b). As she argues, if preverbal subjects were left-dislocated, contrasts like these would remain mysterious.

(46) a. Credevo Gianni avesse telefonato a Maria

believed.2sg Gianni had called to Maria

'I thought Gianni had called Maria'

b. ??Credevo a Roma Gianni avesse vissuto per venti anni believed.2sg in Roma Gianni had lived for twenty years

'I thought Gianni had lived in Rome for twenty years'

Brazilian Portuguese displays other asymmetries of a related kind, involving the distinction between a left-dislocated position (Spec, TopP) and an A-position (Spec, TP) for a preverbal subject. Consider the following contrast: A wh-phrase can freely move overtly to $\mathrm{CP}$ over a preverbal subject under the assumption that the subject is realized in Spec, TP, as shown in (47a). However, it needs to be explained why (47b) is ungrammatical. I argue that the distinct properties of the preverbal subject $o$ Pedro 'Peter' in these two sentences can explain the asymmetry. As I argued above, if the preverbal subject co-occurs with a preverbal co-referential pronoun, this is an indication that the pronoun acts as a resumptive in Spec, TP, whereas the full DP subject is realized in its left-dislocated position (Spec, TopP), as shown in (15), repeated below. This analysis can then be extended to help explain the ungrammaticality of (47b), as opposed to (47a). I argue that if the preverbal subject o Pedro 'Peter' is realized in its left-dislocated position in (47b), overt wh-movement cannot take place over this preverbal subject, whereas this is possible in (47a) because wh-movement proceeds over a preverbal subject in an A-position (Spec, TP). 
(47) a. Quem (que) $\mathrm{L}_{\mathrm{TP}}$ o Pedro convidou quem] ? $^{16}$ who (that) the Pedro invited who

'Who did Pedro invite?'

b. *Quem (que) $\mathrm{L}_{\mathrm{TopP}}$ o Pedro, $\mathrm{L}_{\mathrm{TP}}$ ele convidou quem] ? who that the Pedro be invited who

(15) $E_{\text {TopP }}$ A Silvia,$E_{\mathrm{TP}}$ ela ${ }_{\mathrm{i}} \leftarrow_{\mathrm{T}}$, saiu cedo $]$ the Silvia, she left early

'(As for) Silvia ${ }_{i}$, she ${ }_{i}$ left early'

Goodall (2001) shows a similar effect for Spanish: for him topics, in italics in (48a), create an island for wh-movement, while preverbal subjects do not (48b), assuming again from his analysis that these preverbal subjects are in Spec, TP: ${ }^{17}$

(48) a. *iA quién crees que el premio se lo dieron? to whom think that the prize him it gave

b. ¿A quién crees que Juan le dio el premio? to whom think that Juan bim gave the prize

'Who do you think Juan gave the prize to?'

16 (47a) is different from what Barbosa (2000:65) argues for EP. Following Ambar (1988) she points out that adjacency between a wh-word and the verb is required in matrix clauses, given cases such as:

(i) Quando (*a Maria) veio (a Maria)?

when (the Maria) came (the Maria)

'When did Mary come?'

Barbosa (p. 64) argues that in EP "[... "preverbal" subjects are topics construed with a pro subject." Given this, the restriction in (i) is also apparently compatible with the intervention approach I will suggest for $\mathrm{BP}$ in cases in which the preverbal subject is also construed as a left-dislocated element in TopP.

17 This is apparently different from the proposal made in Goodall 1991, where he argues (for Spanish) that when C has a wh-feature, wh-phrases move to the Spec-IP position on their way to Spec-CP, independently of their grammatical function, therefore banning preverbal subjects when wh-movement applies. He cites contrasts such as:

(i) * ¿Qué puesto Josefina tiene en la empresa? what position Josefina has in the company

(ii) ¿Qué puesto tiene Josefina en la empresa?

What position has Josefina in the company

'What position does Josefina have in the company?'

The restrictions at play here may in fact result not from the structural position of the subject alone, but from additional constraints imposed upon wh-movement in Spanish, possibly requiring verbsubject inversion, along the lines of work going back to Torrego (1984). 
An explanation in terms of minimality can presumably be proposed for related cases in BP, under the assumption that $A^{\prime}$-movement of the wh-phrase cannot proceed across an $A^{\prime}$-position that is occupied by another element. ${ }^{18}$ Interestingly, I show below that although there is a clear intervention effect in specific cases, overt wh-movement is not entirely incompatible with the existence of a left-dislocated subject or other element in Spec, TopP. Consider first the adoption of the analysis of a more complex structure for the CP domain along the lines of Rizzi (1997), which would then allow the possibility of more than one TopP (Topic Phrase) and a Focus Phrase (FocP), in the order presented in the partial structure in (49) (cf. Silva 1996, for early discussion of related phenomena for PB, and for a different use of this approach; see also Lobato 1988). Under that analysis, wh-movement targets FocP, and a wh-phrase can move overtly to FocP provided no element intervenes in an intermediate $\mathrm{A}^{\prime}$-position (in this case, TopP). This can explain the contrast between (47a) and (47b), in that only in the latter a left-dislocated subject occupies (the lower) TopP, blocking wh-movement to FocP (under this view (47b) is structurally like (48a) in Spanish, and in both cases a left-dislocated element in the lower TopP intervenes in the path of wh-movement).

(49) $\left.\cdots \leftarrow_{\mathrm{TopP}} \leftarrow_{\mathrm{FocP}}\left[\left[_{\mathrm{TopP}}\left[_{\mathrm{TP}} \cdots\right]\right]\right]\right]$

The same analysis can explain the ungrammaticality of a case involving a different left-dislocated/topicalized element in (51a). Whereas in (50a) em Roma 'in Rome' can appear as a topicalized element without any problem, I argue that in (51a) 'in Rome' intervenes (by being realized in the lower Spec, TopP) in the movement path of the wh-phrase on its way to FocP, exactly as I argued for the preverbal subject in (47b):

(50) a. [ $\mathrm{T}_{\mathrm{Top}}$ Em Roma $\left[_{\mathrm{TP}}\right.$ vocês podem visitar o Coliseu $\left.]\right]$
in Rome you.pl can visit the Colosseum

b. In Rome you can visit the Colosseum

18 Ordóñez (1997: ch. 5) considers similar restrictions in Spanish, but he argues that they cannot be captured simply in terms of minimality effects, because of complications that apparently do not arise in the BP cases I consider below. 
(51) a. * $\left[_{\mathrm{FocP}} \mathrm{O}\right.$ que (que) $\mathrm{L}_{\mathrm{TopP}}$ em Roma $\mathrm{E}_{\mathrm{TP}}$ vocês podem visitar que]? ${ }^{19}$
the what (that) in Rome you.pl can visit that
b. *What, in Rome, can you visit?

Consider now where the adoption of a second TopP above FocP (as in (49)) becomes relevant. It is in fact possible for an element in Spec, TopP to co-occur with a moved wh-phrase, provided the Topic appears in the higher TopP in (49), as illustrated in (52). This contrast indicates, in a straightforward way, that the left-dislocated phrase in TopP does not intervene in the movement path of the wh-phrase in case the left-dislocated phrase is realized in the higher TopP, above the FocP that is the target of overt wh-movement. ${ }^{20}$ (Notice that a similar analysis can potentially also explain the contrast between (51b) and (52b) in English).

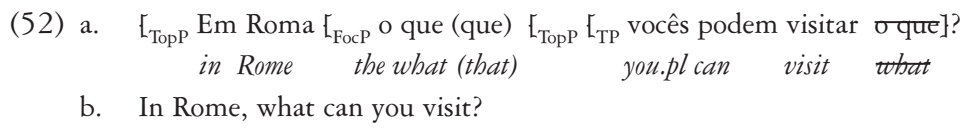

Interestingly, the extended analysis adopting the structure in (49) can also explain in a principled way why overt wh-movement is in fact also compatible with a left-dislocated subject, provided this subject occurs in the bigher TopP, as (53), and not in the lower TopP, as in (47b):

$$
\begin{aligned}
& \begin{array}{c}
\left.E_{\mathrm{TopP}} \mathrm{O} \text { Pedro } E_{\mathrm{FocP}} \text { quem (que) } \mathrm{E}_{\mathrm{TopP}} \mathrm{E}_{\mathrm{TP}} \text { ele convidou quem }\right] \text { ? } \\
\text { the Pedro who (that) }
\end{array} \\
& \text { '(As for) Pedro, who did he invite?' }
\end{aligned}
$$

In related cases, Goodall (2001) argues that preverbal subjects do not occupy a Focus position either. While an embedded Focus phrase would block overt wh-movement as in (54), a preverbal subject (in Spec, TP) does not (as discussed above). The same restriction extends to BP, in that a

\footnotetext{
19 An anonymous reviewer points out that this sentence is not completely ungrammatical in their judgment. More work is necessary to pin down clearly whether there is significant dialectal variation in such cases.

20 The question of whether left dislocation results from movement or base generation in the different cases I consider here may be relevant as well, but not crucial to explain the current contrast. Therefore, I ignore this question in the scope of this paper.
} 
focalized element blocks overt wh-movement (55b), different from a subject in Spec, TP, as I showed above: ${ }^{21}$

(54) * i A quién crees que EL PREMIO le dieron?

to whom think that THE PRIZE him gave

(55) a. ESSE PRÊMIO ele não quer

this prize be not want

'THIS PRIZE he does not want'

b. *Quem ESSE PRÊMIO não quer?

who this prize not want

In this section, I presented evidence involving the use of weak pronouns and intervention effects with wh-movement to show that although subjects can occurs in two different preverbal positions, other grammatical mechanisms can restrict their distribution in different ways.

\subsection{Multiple specifiers of TP?}

Zubizarreta (1998) argues that Tense in Spanish is a syncretic category, whose specifier can accommodate a subject, a topic, or a focused constituent. She analyzes (56) as a topic-comment structure, and takes the topic to occupy the Spec, TP position:

(56) Todos los días compra Juan el diario

every the days buys Juan the newspaper

'Juan buys the newspaper everyday'

However, for her, a preverbal subject is still compatible with a topic in the sentence, as in (57). This is possible in her analysis because there may be multiple topic features to be checked: The possibility of multiple topics is entirely compatible with the analysis I adopted in section 3 with the difference that topics occupy their own Topic phrases. Given this, both a

21 However, notice that a preverbal subject can be focalized in other contexts, in BP:

(i) A LUCIA ganhou um prêmio, e não a Clara

the Lucia won the prize, and not the Clara

'LUCIA won a prize, not Clara' 
left-dislocated subject and another left-dislocated element can co-occur (58), given the structure in (49). Notice, in addition, that since both the preverbal subject and the locative PP are left-dislocated elements, they can vary in their mutual order, depending on the context:

(57) Todos los días, Juan compra el diario

every the days Juan buys the newspaper

'Every day Juan buys the newspaper.'

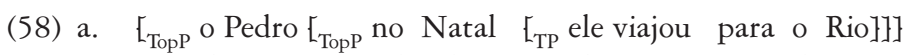
the Pedro in.the Chrismas be traveled to the Rio

'As for Pedro, last Christmas he traveled to Rio'

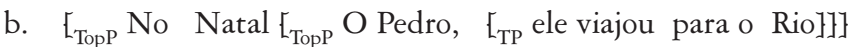
in.the Christmas the Pedro be traveled to the Rio

'Last Christmas, Pedro, he traveled to Rio.'

Zubizarreta (1998) also argues that focused elements can occupy only the Spec, TP position, hence the ungrammaticality of (59), in that the focused phrase 'las espinacas' competes with the same position as the preverbal subject (although here Zubizarreta needs to impose further constraints on the structure to rule this out, given that multiple specifiers are otherwise available):

(59) *Las ESPINACAS, Pedro trajo the SPINACH Pedro brought

'It was the spinach that Pedro brought'

As we turn to BP, we can observe that it is in fact possible for a preverbal subject to co-occur with a focus element. Both options in (61) can be followups to an utterance such as (60). In 61a), the preverbal subject 'Paul' is in Spec, TP. In 61b) 'Paul' is a left-dislocated subject (in TopP) above the focalized object 'Sylvia', whereas a resumptive pronoun co-referent with 'Paul' is realized in Spec, TP.

(60) Speaker A: Me disseram que o Paulo não convidou nem a Ana nem a Silvia para a festa me told that the Paulo not invited neither the Ana nor the Silvia to the party

Speaker A: 'I was told that Paul didn't invite either Ana or Silvia to the party 


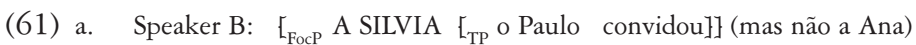
THE SILVIA the Paulo invited (but not the Ana) Speaker B: 'SILVIA, Paulo invited (her) (, but not Anna)' 22

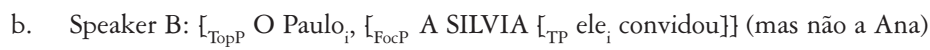
the Paulo THE SILVIA be invited (but not the Ana)

Speaker B: 'Paulo, he invited SILVIA (, but not Anna)'

Again, this analysis is entirely compatible with the proposal I made in the previous section, adopting the possibility that preverbal subjects can be either left-dislocated (in TopP) or in an A-position in Spec, TP.

\subsection{Bare nouns as preverbal subjects}

Turning to a somewhat special case, in his analysis Goodall (2001) argues that bare nouns can be topics in Spanish (62), yet they cannot be subjects, in his terms (in the current terms, they cannot be realized in Spec, TP, as opposed to a topic position (63), cf. Casielles 1997):

(62) Yo a él libros no le dejo

I to him books not him lend

'Books, I don't lend him'

(63) *Libros están muy caros books are very expensive

However, once more, similar cases show a more flexible situation in $\mathrm{BP}$, in that bare nouns do not display the same restriction as in Spanish,

\footnotetext{
22 One may consider as an alternative for (61a) that the preverbal subject actually occurs in the lower TopP, given (49). However, this would leave unexplained why it is that a resumptive pronoun cannot also occur in the sentence (ia). Similar to what I argued for overt wh-movement (which is analyzed as movement to FocP), focalization of other elements can be blocked by the occurrence of another element in the lower TopP, either a preverbal subject (ia) or another topicalized phrase (ib):

(i) a. ?? $\complement_{\text {FocP }}$ A SILVIA $\leftarrow_{\text {TopP }}$ o Paulo, $\leftarrow_{\mathrm{TP}}$ ele convidou] $]$ (mas não a Ana) THE SILVIA the Paulo be invited (but not the Ana) 'SILVIA, Paulo invited (her) (, but not Ana)'

b. ?? $\mathrm{E}_{\mathrm{FocP}}$ A SILVIA $\mathrm{E}_{\mathrm{TopP}}$ hoje cedo $\mathrm{E}_{\mathrm{TP}} \mathrm{O}$ Paulo convidou] ] ] (mas não a Ana) THE SILVIA today early the Paulo invited (but not the Ana) 'SILVIA, this morning Paulo invited (her) (, but not Ana)'
} 
and they can occur either as topicalized elements (64a) or as preverbal subjects in Spec, TP (64b).

(64) a. Livro bom você só acha na livraria do campus

book good you only find in.the bookstore of. the campus

'As for good books, you find them only at the campus bookstore'

b. Aqui em casa criança dorme cedo

here in bouse child sleeps early

'In my home children go to bed early'

Evidence involving wh-movement of the sort I proposed above shows that bare nouns actually need to be realized in Spec, TP in the relevant cases, in order to avoid blocking overt wh-movement (65). If, however, a bare NP appears as a left-dislocated element following a wh-phrase, the sentence is ungrammatical (66), similar to other cases involving left dislocation I considered previously: ${ }^{23}$

(65) a. Onde criança pode brincar com fogo?

where child can play with fire

'Where can children play with fire?'

b. O que (que) cachorro come quando está com fome? the what (that) dog eats when is with hunger

'What do dogs eat when they are hungry?'

(66) * Onde livro bom você consegue encontrar? where good book you manage find

The phenomena discussed in this section provide additional evidence for the argument that preverbal subjects in BP can be realized either in a left-dislocated position (Spec, TopP) or in Spec, TP, yielding various consequences across different domains.

\section{Semantic features as source of structural distinctions?}

In this section, I address the question of whether other properties of DPs can constrain their distribution as subjects in Spec, TP or as left-

\footnotetext{
23 For extensive analysis of the syntax and semantics of bare nouns in Brazilian Portuguese see e.g. Schmitt \& Munn 2003 and references therein.
} 
dislocated elements in BP. In order to constrain the distribution of preverbal subjects in European Portuguese (henceforth EP), Costa (2000) argues that preverbal definite subjects occupy the Spec-IP position while indefinite ones are left-dislocated. He uses evidence from A-Binding, A-bar Minimality effects as well as distributional evidence to support his arguments.

Costa argues that in European Portuguese preverbal definite subjects are A-Binders (67a), induce no A-bar Minimality effects (68) (similarly to what I showed in the previous section for BP in (47a)), and do not compete for a preverbal position with other left-dislocated elements (69). The corresponding examples behave similarly in BP. In the case of A-binding, the only small change in BP is that a different bindee is preferred, as shown in (67b) (see also the cases I discussed before in (37) and (38)). Costa argues that these properties follow from the fact that definite subjects occupy the Spec, IP (Spec, TP here) position in EP. However, differently from what Costa's analysis seems to indicate for EP, I have shown various grammatical examples in which definite DPs are not restricted to Spec, TP in BP, but in fact occur in a left-dislocated position, as in (15), (17), (35), (42) and (53).

(67) a. Todos os coelhos ${ }_{\mathrm{i}}$ comem a sua $\mathrm{i}_{\mathrm{i}}$ cenoura all the rabbits eat the their carrot

'All the rabbits ${ }_{i}$ eat their ${ }_{i}$ carrot'

b. Todos os coelhos $_{\mathrm{i}}$ cuidam da propria ${ }_{\mathrm{i}}$ cria (BP) (see also (37) and (38)) all the rabbits take.care of.the own offspring

'All the rabbits take care of their ${ }_{i}$ offspring'

(68) Que livro o Paulo leu?

$(\mathrm{EP} / \mathrm{BP})($ see also $(47 \mathrm{a}))$ what book the Paulo read.past

'What book did Paulo read?'

(69) Com o Pedro, o Paulo falou sobre o Big Bang $(\mathrm{EP} / \mathrm{BP})$ with the Pedro the Paulo talked about the Big Bang 'As for Pedro, Paulo talked to him about the Big Bang'

In addition, Costa argues that in EP preverbal indefinite subjects cannot be A-Binders (70), do induce A-bar Minimality effects (71), and are in complementary distribution with left-dislocated elements (72). Costa argues that this is so because these restrictions apply to left-dislocated elements, and preverbal indefinite subjects can only be left-dislocated elements in EP: 
(70) ?? Uma criança ${ }_{i}$ gosta da sua ${ }_{i}$ mãe a child likes of.the his mother

(71) * Que livro um homem leu? what book a man read.past

(72) *A sopa, um cão comeu the soup a dog ate

However, certain cases indicate that this ungrammaticality does not extend to all cases of preverbal indefinite subjects in BP. First, indefinites can occur as A-binder, in cases such as (73)-(75), especially in case of hypothetical situations, possibly with the use of certain modal elements in the clause:

(73) Dependendo da situação, uma criança ${ }_{i}$ é capaz de gritar com a (sua) própria ${ }_{i}$ mãe depending of.the situation, a child ${ }_{i}$ is capable of yelling at the their own ${ }_{i}$ mother 'Depending on the circumstances, a child ${ }_{i}$ may yell at their own mother'

(74) No Rio, um/qualquer policial ${ }_{i}$ venderia a própria ${ }_{i}$ alma para se aposentar aos 70 in.the Rio, alany police.officer ${ }_{i}$ would.sell the own ${ }_{i}$ soul to self retire at.the 70 'In Rio a/any police officer ${ }_{i}$ would sell their own ${ }_{i}$ soul to retire at the age of 70 '

(75) Com essa vida, um/qualquer professor $_{i}$ venderia a própria $_{i}$ alma antes de se aposentar with this life, alany teacher, would.sell the own ${ }_{i}$ soul before of self retire 'With this life, a/any teacher ${ }_{\mathrm{i}}$ would sell their own ${ }_{\mathrm{i}}$ soul before retiring'

In addition, cases such as (74)-(75) show that left-dislocated elements can co-occur with indefinite preverbal subjects, although this is not sufficient evidence to rule out the possibility that the indefinite subject are leftdislocated, in such cases, especially if we allow multiple left-dislocated elements, as topics or focus, as compatible with (49). However, if the analysis I proposed in section 3 for wh-movement in the presence of a preverbal subject is on the right track, the following cases can only be possible if the indefinite preverbal subject is in fact in a non left-dislocated position, arguably Spec, TP, contrary to what Costa argued for EP, because this is the only way intervention effects can be avoided in the movement path of the wh-phrase: 
(76) a. O que um cachorro comeria se estivesse faminto?

the what a dog would.eat if were starving

'What would a dog eat if he were starving?'

b. O que um bombeiro faz para apagar um incêndio na floresta? the what a firefighter does to extinguish a fir $e$ in.the forest 'What does a firefighter do to extinguish a fire in the woods?'

In sum, the cases discussed in this section show that a definiteness distinction does not impose a restriction on the possible position of a preverbal subject in BP. Contrary to what Costa seems to argue for EP, in BP either definite or indefinite DPs can occur both in a left-dislocated position (Spec, TopP) or in a A-position (Spec, TP).

\section{Conclusion}

In this paper, I have provided substantial evidence that there are very few restrictions imposed on the treatment of overt preverbal subjects in Brazilian Portuguese (BP). I have argued in detail that, contrary to proposals that have been made for other languages, including primarily Spanish, BP allows preverbal subjects to be realized either as left-dislocated elements (as topics) or as arguments internal to the clause, in Spec, TP. Whether preverbal subjects occur in one or the other way determines how they affect or are affected by other structural properties of the clause. This includes their possible co-occurrence with co-referential resumptive pronouns, their ability to function as A-binders, their role in blocking or allowing overt wh-movement to take place, and their ordering with respect to other preverbal elements in the clause.

The scope of the arguments made in this paper was restricted to Brazilian Portuguese. However, the fact that some of the proposals that I used as background make similar arguments for other languages, especially Spanish, suggests that more significant similarities between these languages may actually exist. If this is so, a more accurate picture of the treatment of preverbal subjects in Spanish (and possibly other null subject languages as well), may in fact show that both Spec, TP and a left-dislocated position (Spec, TopP) are possible positions for preverbal subjects, depending on the structural properties of different clauses. I leave further investigation of these possible consequences for future work.

E-mail: pires@umich.edu 


\section{REFERENCES}

Alexiadou, A \& A. Anagnostopoulou. 1998. Parameterizing Agr: Word order, V-movement and EPP-checking. Natural Language and Linguistic Theory 16:491-531.

Ambar, M. 1988. Para uma sintaxe da inversão sujeito-verbo em português. Ph.D. dissertation, University of Lisbon. [published 1992. Lisbon: Colibri].

Barbosa, P. P. 1996. Clitic placement in European Portuguese and the position of subjects. In: A. Halpern \& A. Zwicky (eds.) Approaching second: Second position clitics and related phenomena. Stanford: CSLI.

. 2000. Clitics: A window into the null subject property. In: J. Costa (ed.) Portuguese syntax: New comparative studies. Oxford: Oxford University Press.

. 2006. Ainda a questão dos sujeitos pré-verbais em PE: Uma resposta a Costa (2001). D.E.L.T.A. 22.2: 345-402.

BARss, A. 1986. Chains and anaphoric dependence: On reconstruction and its implications. Ph.D. dissertation, MIT.

Belletti, A. 1990. Generalized verb movement. Turin: Rosenberg and Sellier.

BritTo, H. 2001. Syntactic codification of categorical and thetic judgments in Brazilian Portuguese. In: M. Kato \& E. V. Negrão (eds.) Brazilian Portuguese and the Null Subject Parameter. Madrid: Iberoamericana, Frankfurt am Main: Vervuert.

Cardinaletti, A. 1999. Subjects and clause structure. In: L. Haegeman (ed.) The new comparative syntax. London: Longman.

\& M. Starke. 1999. The typology of structural deficiency. A case study of the three classes of pronouns. In H. van RiEMSDIjK (ed.) Clitics in the languages of Europe. Berlin: Mouton de Gruyter.

CAsIelles, E. 1997. Topic, focus and bare nominals in Spanish. Ph.D. dissertation, University of Massachusetts, Amherst.

Chomsкy, N. 1995. The Minimalist Program. Cambridge, MA: MIT Press. . 2000. Minimalist inquiries: The framework. In: R. MARTIN, D. Michaels, \& J. URIAGEREKA (eds.) Step by step: Essays on minimalist syntax in honor of Howard Lasnik. Cambridge, MA: MIT Press.

. 2001. Derivation by phase. In: M. Kenstowicz (ed.) Ken Hale: A life in language. Cambridge, MA: MIT Press.

CINQUE, G. 2002. Functional structure in DP and IP: The cartography of syntactic structures. Vol. 1. Oxford: Oxford University Press. 
Contreras, H. 1991. On the position of subjects. In: S. Rothstein (ed.) Perspectives on phrase structure: Heads and licensing. Syntax and Semantics 25. San Diego: Academic Press.

Costa, J. 2000. Word order and discourse-configurationality in European Portuguese. In: J. Costa (ed.) Portuguese syntax: New comparative studies. Oxford: Oxford University Press.

. 2001. Spec, IP or deslocado? Prós e contras das duas análises dos sujeitos pré-verbais. D.E.L.T.A. 17.2: 283-303

Cyrino, S. \& G. Matos. 2002. VP ellipsis in European and Brazilian Portuguese: a comparative analysis. Journal of Portuguese Linguistics 1.2: 177-95.

Duarte, M. E. L. 1995. A perda do princípio "evite pronome" no português brasileiro. Ph.D. dissertation, University of Campinas.

Epstein, S. D. \& T. D. Seely. 2006. Derivations in Minimalism: Exploring the elimination of A-chains and the EPP. Cambridge: Cambridge University Press.

Ferreira, M. 2000. Argumentos Nulos em Português Brasileiro. MA thesis, University of Campinas.

GaLves, C. 2001. Ensaios sobre as gramáticas do português. Campinas: Editora da Unicamp.

Goodall, G. 1999. On preverbal subjects in Spanish. In: T. SATterfield, C. Tortora \& D. Cresti (eds.) Current issues in Romance Languages: Selected papers from the 29th Symposium on Romance Languages (LSRL), Ann Arbor, 8-11 April 1999. Amsterdam: John Benjamins.

. 2001. The EPP in Spanish. In: W. D. Davies \& S. Dubinsky (eds.) Objects and other subjects: Grammatical functions, functional categories and configurationality. Dordrecht: Kluwer.

. 1991. On the status of Spec of IP. In: D. Bates (ed.) Proceedings of the $10^{\text {th }}$ West Coast conference on Formal Linguistics. Stanford: CSLI.

Kato, M. 1999. Strong pronouns, weak pronominals and the null subject parameter. Probus 11.1: 1-37.

. 2000. The Partial Pro-Drop Nature and the Restricted VS Order in Brazilian Portuguese. In:_M. Kato \& E. V. Negrão (eds.) Brazilian Portuguese and the Null Subject Parameter. Madrid: Iberoamericana, Frankfurt am Main: Vervuert.

Lasnik, H. 2001. Subjects, objects, and the EPP. In: W. Davies \& S. Dubinsky (eds.) Objects and Other Subjects. Dordrecht: Kluwer.

Lobato, M. L. P. 1988. Sobre a regra da anteposição do sujeito no português do Brasil. D.E.L.T.A. 4:121-47. 
May, R. 1985. Logical Form. Cambridge, MA: MIT Press.

Modesto, M. 2000. Null subjects without rich agreement. In: M. Kato \& E. V. Negão (eds.) Brazilian Portuguese and the Null Subject Parameter. Madrid: Iberoamericana, Frankfurt am Main: Vervuert.

Montalbetti, M. 1984. Binding: On the interpretation of pronouns. Ph.D. dissertation, MIT.

NegÃo, E. V. 1999. O português brasileiro: Uma língua voltada para o discurso. Tese de Livre Docência, University of São Paulo.

\& E. Viотті. 2000. Brazilian Portuguese as a discourse-oriented language. In: M. Kato \& E. V. Negrão (eds.) Brazilian Portuguese and the Null Subject Parameter. Madrid: Iberoamericana, Frankfurt am Main: Vervuert.

ORDÓÑEZ, F. 1997. Word order and clause structure in Spanish and other Romance languages. Ph.D. dissertation, City University of New York.

Pilati, E. 2006. Aspectos sintáticos e semânticos das orações com ordem VerboSujeito no Português do Brasil. Ph.D. dissertation, University of Brasília. Pollock, J-Y. 1989. Verb movement, Universal Grammar and the structure of IP. Linguistic Inquiry 20: 365-424.

Pontes, E. 1987. O tópico no português do Brasil. Campinas, São Paulo: Pontes. Riemsdijk, H. \& E. Williams. 1986. Introduction to the theory of grammar. Cambridge, MA: MIT Press.

Rizzi, L. 1997. The fine structure of the left periphery. In: L. HAEGEMAN (ed.) Elements of grammar. Dordrecht: Kluwer.

Rodrigues, C. 2004. Weak morphology and A-movement out of Case domains. Ph.D. dissertation, University of Maryland.

Schmitt, C., \& A. MunN. 2003. The syntax and semantics of bare arguments in Brazilian Portuguese. Linguistic Variation Yearbook 2: 185-216.

Silva, M. C. F. 1996. A posição sujeito em português brasileiro: Em frases finitas e infinitivas. Campinas, São Paulo: Editora da Unicamp.

Suñer, M. 2003. The lexical preverbal subject in a Romance Null Subject Language. In: R. Núñez-Cedeño, L. Lópes \& R. Cameron (eds.) $A$ Romance perspective on language knowledge and use: Selected papers from the $31^{\text {st }}$ Linguistic Symposium on Romance Languages (LSRL), Chicago, 19-22 April 2001, ed.. Amsterdam: John Benjamins.

Torrego, E. 1984. On inversion in Spanish and some of its effects. Linguistic Inquiry 15:1.

Zubizarreta, M. L. 1992. Word order in Spanish and the nature of nominative Case. Ms., Los Angeles, CA: USC. . 1998. Prosody, focus and word order. Cambridge, MA: MIT Press. 